\title{
LEGAL AND POLICY FRAMEWORK FOR RENEWABLE ENERGY AND ENERGY EFFICIENCY DEVELOPMENT IN VIETNAM
}

TRAN VIET DUNG

International law Department, Hochiminh city University of Law

Email: tvdung@hcmulaw.edu.vn

\begin{abstract}
Vietnam has experienced an economic growth accompanied by increasing energy demand and inadequate supplies. Like most developing countries, the increased inefficient use of energy in Vietnam leads to increased greenhouse gas emissions and high energy costs for consumers. Also, the traditional sources of energy are not sufficient to satisfy the demand of the economic sectors.

With the negative impact of climate change on water resources and the depletion of coal, oil and gas reserves, Vietnam must diversify and integrate other forms of renewable energies into its energy mix. The efficient use of renewable energy resources can boost economic development. Thus, the policies for endorsing renewable energies and energy efficiency are playing a vital role in ensuring the sustainable development for Vietnam's future. This paper examines the legal and policy framework influencing the deployment of renewable energies and energy efficiency in Vietnam. The paper also attempts to identify major barriers to a large scale deployment of renewable energies and energy efficiency technologies and offers some possible solutions.
\end{abstract}

Keywords: Vietnam, renewable energy, electricity, Power Development Master Plan VII

\section{Introduction}

Energy is essential to modern society, to economic development, and to maintain and raise living standards. The pursuit of economic growth and a better quality of life in developing countries is driving global energy demand. New supplies of reliable and affordable energy are needed. At the same time, concerns about future energy supply and climate change have heightened the interest in energy supplies options, energy prices and the effect of energy use on the environment. It is essential that industry plays an active role in the ongoing dialogue on the future of energy - one that is grounded in reality, focused on the long term and intents to find viable solutions.

During the last three decades, Vietnam has experienced sustained economic growth (average economic growth rate of 6.2\%/year (from 20002017), total GDP in 2017 recorded at USD 223 billion) ${ }^{1}$ accompanied by an increase demand in energy consumption. As the economy continues to grow, this creates an 'hunger' for energy, given that economic growth largely depends on access to reliable and affordable energy. ${ }^{2}$ During the last

The World Bank (2018), The World Bank in Vietnam, retrieved from https://www. worldbank.org/en/country/vietnam/overview. [aceessed 19 December 2018].

Phung Thanh Binh (2011), 'Energy Consumption and Economic Growth in Vietnam: Threshold Cointegration and Causality Analysis', International Journal of Energy Economics and Policy, vol. 1, no. 1, , pp. 1-17. 
decade, the growth of demand in energy consumption has been around 9.5\%/year in average. In 2016-2017 the energy consumption of Vietnam was recorded at over 184 billion $\mathrm{kWh} /$ year. ${ }^{3}$ However, the national power system can currently generate about 170 billion $\mathrm{kWh}$ of electricity annually only. According to the targets of the revised Power Development Master Plan (PDMP) VII issued in March 2016 (the "Revised PDMP VII"), ${ }^{4}$ by 2025 , the country would need an electricity output of about 400 billion $\mathrm{kWh}$ /year, and by 2030 the electricity output shall be of more than 570 billion $\mathrm{kWh}$ /year. ${ }^{5}$ The leadership of Vietnam has openly admitted that the energy security is one of the key and emerging considerations of the State in the recent period of development. ${ }^{6}$

Access to energy is a key component to meet the sustainable development goals of Vietnam, in light of its national industrial development strategy until $2030 .^{7}$ To date, Vietnam's three main sources of energy are hydropower, gas thermal power and coal thermal power, accounting for over $94 \%$ of the total power capacity of the country's electricity system.

\section{Figure 1: Share of Primary Energy Sources in Vietnam}

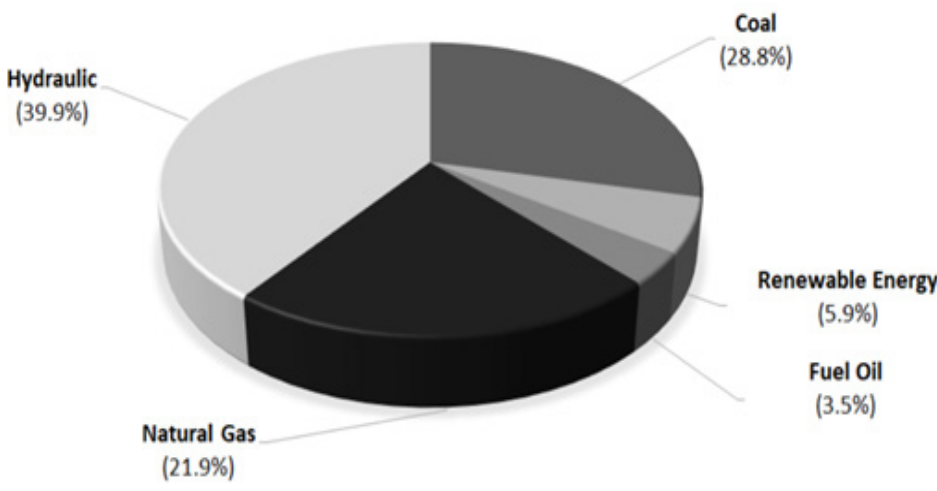

(Source:

EVN, 2018)

The traditional source of power generation in Vietnam has been large and small hydropower plants, which have been estimated to be responsible for nearly $39.9 \%$ of the total installed power generation capacity. In recent years, there has also been significant developments in coal thermal power plants (which account for approximately $28.8 \%$ of the total installed capacity and are mostly located in the North and central regions of Vietnam) as well as

\footnotetext{
3 Vietnam Electricity Corporation (EVN) (2018), Báo cáo tổng kết hoạt dộng sản xuất kinh doanh ngành diẹn luc 2018 [Report on production and business activities of electric industry in 2018].

4 Decision 428/QD-TTg on master plan on the national electricity development in the period of 2011 to 2020 with vision to 2030 (2016), which replaced Decision 1208/QD-TTg by the Prime Minister approving the national master plan for power development in the 2011-2020 period, with considerations to 2030, (2011). Ibid.

Communist Party of Vietnam (CPV) (2018), Politburo Resolution No. 23-NQ/TW on the orientation of developing national industrial development policies till 2030, with a vision to 2045.

Ibid.
} 
in gas-thermal power plants in the South (which account for approximately $21.9 \%$ of the total installed capacity). ${ }^{8}$

Although Vietnam has energy sources from the above mentioned power productions, it is not self-sufficient in energy. According to Mr. Hoang Quoc Vuong, Deputy Minister of Trade and Industry, "coal resources of Vietnam have a medium potential, but the level of exploration is still very limited, the reliability is very low, especially in traditional mining areas, showing signs of entering a period of decline. Coal production and supply output does not meet the growing demand for coal for electricity production. Similarly, the exploration of natural gas at the gas fields of Block B and Blue Whale [in the East Sea] is now only enough for the operation of the O Mon thermal power complex". ${ }^{9}$ Thus, Vietnam has to import coal and gas for its energy production, and this reliance on imports will continue in the future given the growing energy demand of the country. ${ }^{10}$ Given that most large hydropower plant projects have already been developed and are contributing to environmental concerns, as well as the relatively slow development of the natural gas industry and the Government's recent decision to suspend nuclear power development, renewable energy (other than hydropower) is generally viewed as a viable alternative to meet Vietnam's future power needs. However, promoting the exploration and use of renewable energy is not a simple task as it would face various barriers.

This paper examines the legal and policy framework influencing the deployment of renewable energies and energy efficiency in Vietnam. The paper identifies major barriers to large scale deployment of renewable energies and energy efficiency technologies and suggests recommendations for improvement.

\section{Vietnam's renewable energy potential and status of exploitation}

Renewable energies offer the opportunity for a sufficient and secured global energy supply. According to statistics, the amount of renewable energies (including biomass, solar, wind and waves) reaching the earth is equal to 12,000 times the present world's energy consumption. Thus, there are no natural limitations to its use which would benefit mankind. ${ }^{11}$ Due to limited fossil and nuclear resources, it is obvious that the steady growth of renewable energy use will be the future of the energy industry around the

\footnotetext{
$8 \quad$ Figures taken from website of the Ministry of Industry and Trade (2018), retrieved from http://www.moit.gov.vn/tin-chi-tiet/-/ chi-tiet/giai-ma-su-ton-tai-cua-cac-nha-maynhiet-\%C4\%91ien-than-108230-16.html, [aceessed 19 December 2018].'

Hoang Quoc Vuong (2018), 'Ngành năng lựng Việt Nam đang phải đối mặt với nhiè̀u thách thức lớn' [Energy industry of Vietnam faces big challenges], VNmedia, 10/8/2018, retrieved from http://www.vnmedia.vn/kinh-te/201808/nganh-nang-luong-viet-nam-dang-doi-mat-voinhieu-thach-thuc-lon-611423, [aceessed 12 November 2018].

Revised PDMP VII (Decision No. 428/QĐ-TTg) (2016).

11 Preben Maegaard (2017), Balancing of Fluctuating Power to Obtain100 \% Supply with Renewable Energy, in Tanay Sidki Uyar (ed.), Towards 100\% Renewable Energy - Techniques, Costs and Regional Case-Studies, Springer, p. 137.
} 
world. Recent decades have witnessed an increasing number of countries switching their energy policies from scarce fossil and nuclear resources towards local renewable resources, as the former implies high political and economic risks. Comparatively, renewable energy is a clean source of energy which has the potential to contribute efficiently to a more ecologically, socially and therefore economically sustainable future for the planet. ${ }^{12}$

Vietnam is rich in renewable energy sources. Its potential sources include biomass, biogas, solar and wind energy. Due to its geographical location and landscape, Vietnam has a high potential for solar and wind energy use in terms of concentration and amount of available areas. Accordingly, more than $57 \%$ of its terrain is exposed to concentrated sunlight all year round. The natural solar energy intensity is recorded at around $5 \mathrm{kWh} / \mathrm{m}^{2}$ on average. Theoretically, the potential for solar in Vietnam is of 60-100 GWh/year for concentrated solar power and of 0.8-1.2 GWh/year for photovoltaic systems. ${ }^{13}$ Vietnam also has an enormous potential for developing wind energy, having a coastal line of 3,400 kilometres with an average wind speed of 6 meters/second. The total power generating potential for wind energy is estimated to be at 500 to $1000 \mathrm{kWh} / \mathrm{m} 2 /$ year. ${ }^{14}$ Besides, it is estimated that Vietnam can also produce 73 million tonnes of total biomass energy potential a year, which includes 60 million tonnes from agriculture, forestry and fisheries and 13 million tonnes from waste, which are conservatively estimated at 5,000MW. ${ }^{15}$ Despite the abundance of renewable energy in Vietnam, its use is currently negligible; only nearly $5.9 \%$ of the final energy consumption comes from renewables. ${ }^{16}$

Table 1: Electricity demand: Actual (2005-2014) and projected (2015-2030)

\begin{tabular}{|l|c|c|c|c|c|c|c|}
\hline \multicolumn{1}{|c|}{ Item } & 2005 & 2009 & 2014 & 2015 & 2020 & 2015 & 2030 \\
\hline Annual demand (TWh) & 45.6 & 76.0 & 128.4 & 141.8 & 234.6 & 352.3 & 506.0 \\
\hline Annual generation (TWh) & 53.6 & 86.9 & 145.5 & 161.3 & 265.4 & 400.3 & 571.8 \\
\hline Maximum demand (GW) & 9.5 & 13.9 & 22.2 & 25.3 & 42.1 & 63.5 & 90.7 \\
\hline Per Capita consumption (KWh) & 549 & 873 & 1,415 & 1560 & 2,545 & 3,610 & 4,950 \\
\hline
\end{tabular}

(Source: EVN, 2017)

The number of large scale renewable energy projects is very small and mainly at a pilot level. The main obstacle for the access and exploitation of

12 Herrmann Scheer (2006), Energy autonomy, the economic, social and technological case for renewable energy, Earthscan, pp. 3-14.

13 MOIT, Report "Maps of solar resource and potential in Vietnam", dated 21/01/2015.

14 MOIT, Report "Potential for renewable energy development", dated 26/5/2016; see also, retrieved from http://nangluongvietnam.vn/news/en/nuclear-renewable/expectations-onrenewable-energy-development.html, [aceessed 20 December 2018].

MOIT, supra note 12 .

Supra note 2 
renewable energy sources remains the traditional attachment to the fossil fuelbased energy system. Energy developers are still considering renewable energies as high costs and difficulties in connecting the projects to the electricity grid, as well as a need for larger land funds. Thus, the promotion of the use of renewable energies needs a strong and solid support from State and society.

\section{Renewable energy legal and policy framework}

A renewable energy policy is the main driver for the growth of the use of renewable energies. To initiate the development and promotion of the exploration of renewable energies, countries must have specific renewable energy policies, which would provide some forms of national policy targets or support schemes for such energies.

In 2007, Vietnam adopted for the first time the national energy development strategy with an outlook to $2050,{ }^{17}$ which includes the following key objectives:

a) ensure national energy security;

b) supply sufficiently high-quality energy for socio-economic development;

c) exploit and manage efficiently the domestic primary energy resources;

d) diversify energy investments and business models;

e) establish and develop a competitive energy market;

f) promote new and renewable energy sources; and

g) develop energy resources effectively and sustainably with consideration for environmental protection.

The energy development strategy was developed to address the five major challenges of Vietnam in its process of industrialisation, namely: a strengthening in the energy supply security, continuously increasing energy costs, a greater dependency on energy imports, increasing pollution emissions and an increasing volume of $\mathrm{CO} 2$, which resulted from the continuously increasing energy demand.

The leadership of Vietnam has gradually admitted the importance of the exploration of local renewable energies. ${ }^{18}$ The government has taken several steps to promote the development of this sector and to encourage investments in renewable energies in the recent years. In 2014, the National Assembly amended the Electricity Law ${ }^{19}$ and the new Law on Environmental Protection (the "Environmental Law") ${ }^{20}$ to strengthen the legal framework for the exploration of energy resources. Also, the Electricity Law has set the basis for the development of renewable energy projects. ${ }^{21}$ Meanwhile, the

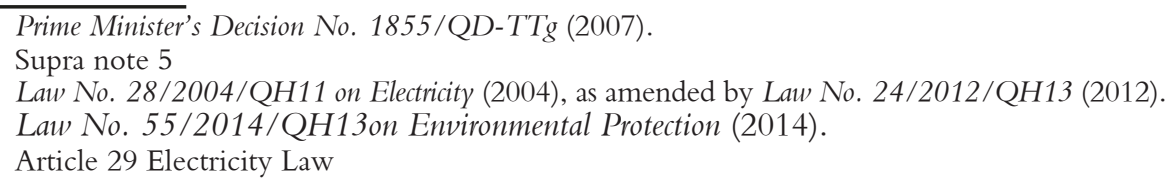


Environmental Law has defined clearly the applicable scope of renewable energies and emphasizes the government preferential treatment for the extract and use of green and renewable energies. ${ }^{22}$

In 2011, the government adopted its 10-year development plan from 2011 to 2020 in the original Power Development Master Plan VII (the "Original PDMP VII"), in which, for the first time, was determined the proportion of renewable energy sources. ${ }^{23}$ In particular, the Original PDMP VII sets out a goal of a $4.5 \%$ share of the total power generation capacity to be covered by renewable energies by 2020 , and of $6 \%$ by 2030 . In 2016 , the Government has revised the PDMP VII to further increase these targets to $7 \%$ and $10 \%$, respectively.

To promote the goals set out in the Original PDMP VII, the Prime Minister issued Decision 2068/QĐ-TTg ${ }^{24}$ in November 2015 approving a renewable energy source development strategy and including steps to be implemented by 2030 with a view to longer-term considerations up to 2050 (the "Renewable Energy Decision"). The Renewable Energy Decision includes various incentives to be developed by the Ministry of Industry and Trade (MOIT) for renewable energy projects, including, in particular, higher tariffs, tax incentives, land related incentives and subsidies to be granted for research related to renewable energies. The revised PDMP VII, which increases the target of production of electricity generated from renewable energies to $10 \%$ by 2020 , would create a side benefit of reducing greenhouse gas emissions overall.

The government has introduced several important investment incentives for renewable energies to attract investments from various economic sectors. Accordingly, companies investing in renewable energy production are entitled to a preferential corporate income tax rate of $10 \%$ for the first 15 years ${ }^{25}$ (the normal corporate income tax rate is of $20 \%$ ). There is also an exemption from import duties in respect of goods imported for developing renewable energy projects. In addition, investor(s) of any renewable energy project may be entitled to an exemption from land use fees for up to 11 years, and if the project is located in an area with extreme socio-economic difficulties, this period can be extended to 15 years. ${ }^{26}$ During the capital construction period of a project (being the period of construction of a new building or plant for

$22 \quad$ Article 5 and 43, Environmental Law

23 Decision 428/QD-TTg on master plan on the national electricity development in the period of 2011 to 2020 with vision to 2030 (2016).

24 Decision 2068/QD-TTg of the Prime Minister, Approving the Viet Nam's Renewable Energy Development Strategy up to 2030 with an outlook to 2050 (2015).

25 Article 15, Decree No. 218/2013/ND-CP, Detailing and guiding the implementation of the Law on Corporate Income Tax (2013).

26 Article 19.3, Decree No. 46/2014/ND-CP, Regulations on collection of land rent and water surface rent (2014). 
up to 3 years from the effective date of the land lease contracts), investors are also entitled to exemption from land rents and water surface rents. ${ }^{27}$

Overall, Vietnam's general policy aims at encouraging investors from various economic sectors, both foreign and domestic, to participate in renewable energy projects in order to form a dynamic renewable energy market. Indeed, there are no foreign ownership restrictions on renewable energy projects.

Nevertheless, the price regime for renewable energy, which is one of the key elements to promote this type of energy, has yet to be properly developed. The policy framework does not set up the common Feed-inTariff (FIT) system for renewable energies. The 2015 Renewable Energy Decision of the Prime Minister is silent about this issue, and the FIT is regulated in different government's decisions that targets at particular type of renewable energies and usually has a short-term period. For instance, Decision 11/2017/QD-TTg ${ }^{28}$ of the Prime Minister has introduced an attractive FIT for solar energy projects that can be implemented near a connection point of the national power grids. Accordingly, for on-grid photovoltaic (PV) power projects, the electric buying price is about $0.935 \mathrm{US}$ cents $/ \mathrm{kWh}$ (excluding VAT) ${ }^{29}$ which is relatively attractive for international investors. ${ }^{30}$ However, it should be noted that this price is only applicable to on-grid PV power projects satisfying either (i) an efficiency of solar cells greater than $16 \%$ or (ii) an efficiency of the module greater than $15 \% .{ }^{31}$ On top of it, this special price is applicable to power plants whose commercial operation date (COD) $)^{32}$ starts before June 30, 2019, and will last for 20 years from the commercial operation date. It is believed that for the purpose of attracting investments in renewable energies, Vietnam shall define a general strategy/policy for FIT for all type of renewable energies, as it would ensure transparency and predictability for investors that engage in renewable energy projects.

\section{Establishment of Competitive Energy Generation and Distribution Markets: Next steps and Challenges}

Historically, Vietnam's energy sector was heavily controlled by the

29

30

31

32

\footnotetext{
Article 19.3, Decree No. 46/2014/ND-CP, Regulations on collection of land rent and water sufface rent (2014). Decision No. 11/2017/QD-TTg of the Prime Minister dated 11 April 2017 on encouragement mechanism for development of solar power projects in Vietnam (2017) (Decision 11/2017/QD-TTg). Article 12 of Decision No. 11/2017/QD-TTg (2017).

The FIT for Biomass is $5.8 \mathrm{US}$ cents/kWh, while the FIT for wind energy is $8.5 \mathrm{US}$ cents $/ \mathrm{kWh}$ (as of $1 / 11 / 2018$ ), however, some off-shore wind energy project can enjoy 9.8 cents/kWh. Article 12.1, Decision No. 11/2017/QD-TTg.

Commercial operation date (COD) means the day on which part of or the entire on-grid PV power plant is able to sell electricity to the buyer, and satisfies the following requirements: (i) the power plant has fully completed all tests of a part of or the entire on-grid PV power plant, and point connecting equipment; (ii) the on-grid PV power plant has obtained the license for generating electricity; (iii) the seller and the buyer has reached an agreement on a meter index to make the payment (Article 3 of Circular No. 16/2017/TT-BCT of the MOIT on project development and model Power Purchase Agreements applied to solar power projects (2017)).
} 
government and dominated by a state-owned electricity corporation. Energy liberalisation is expected to create a competitive market for and between different forms of energies. In turn, the market will facilitate competition for energy and energy services, as well as lowering the prices of energy and/ or services. A competitive energy generation and distribution market shall encourage private investments in the energy sector, especially in renewable energy projects, given the restrain of governmental funds and the dramatically increasing energy requirements.

Energy liberalization, which is also known as privatization and deregulation, is resulting in competitive markets for and between different forms of energy. These competitive energy markets exist or are developing throughout the world. In North America, markets have been embraced to introduce competition for energy and energy services, and to lower the price of that energy or service. Competitive energy markets are being encouraged in Europe to lower energy prices, maintain industrial competitiveness, and develop an internal European market. Energy markets have been introduced throughout South America to encourage private investment in the energy sector, given insufficient government funds and dramatically increasing energy requirements.

The role of energy regulation changes as competitive markets emerge. Under this regulatory framework, state or private utilities were required to make non-economic decisions for renewable energy or energy efficiency through legislation, and regulatory initiatives and decisions. These decisions were non-economic as they did not increase utility revenues. Specific examples include requirements that utilities promote demand side management to reduce overall energy demand, and that they purchase electricity from independent thermal or renewable generation at regulated prices that exceeded their costs of generation.

Energy liberalisation is expected to create competitive markets for and between different forms of energy. The markets in turn will facilitate competition for energy and energy services, and lower the price of the energy and/or service. Competitive energy generation and distribution market shall encourage private investment in the energy sector, especially in renewable energy projects, given the restrain of governmental funds and dramatically increasing energy requirements.

The Government of Vietnam has begun taking steps to transform the energy market by introducing a roadmap to restructure this market, which aims at promoting a competitive market-driven environment under the Decision No. 63/2013/QD-TTg. ${ }^{33}$ It is assumed that a competitive generation market

33 Decision No. 63/2013/QD-TTg by the Prime Minister regarding electricity market formation roadmap (2013). 
would help to achieve stable power supply and price, attract investments to the industry, encourage competition in the generation market, and promote transparency in the market and system operations and electricity pricing.

The roadmap comprises three levels:

* Level 1 - The establishment of a competitive power generation market by the end of 2014, which - according to the authorities - was completed on schedule.

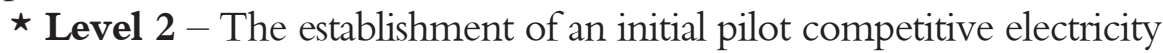
wholesale market during 2015 and 2016, with purchasers including the State-owned Electricity of Vietnam ("EVN") and other permitted wholesale purchasers. The foundations for this, including relevant regulations and the (on paper) simulated pilot model, have been implemented since 2017. This should then be followed by a second phase, which contemplates a complete competitive wholesale electricity market by 2021.

^ Level 3 - The establishment of a competitive retail electricity market.

Currently, licensed power plants that are connected to the electricity grid are required to compete in the market. Hydropower plants are given no more than 6 months from the commencement of commercial operations to participate in the market, while other power plants have a grace period of 12 months. Electricity trading is carried out either through definite-term contracts or spot trading with EVN. However, even with the creation of a competitive generation market, only $10 \%$ of the sales are made at spot market prices while the rest are made at prices that are negotiated in standard power purchase agreement (PPA) between the generator and EVN and according to the template agreement stipulated by the MOIT. Under the template PPA, EVN is named as the sole purchaser of energy generated from all energy projects in Vietnam. Theoretically, the parties can negotiate the terms and conditions of the PPA, but market information suggests that EVN does not negotiate outside the scope of the agreement. ${ }^{34}$ It is observed that PPA contains many terms that increase the costs and risks for investors, hence reducing the bankability of projects. ${ }^{35}$ Given the fact that EVN has a monopoly power in the market, it has the right to stop purchasing electricity in circumstances that are outside seller's control, and without having to provide any compensation.

34 Allens (2018), 'Renewable Energy in Vietnam: Opportunities for Investment', retrieved from https://www.allens.com.au/pubs/pdf/asia/vietnam-renewables-2018.pdf, [aceessed 10 January 2019].

35 Ibid. see also Baker McKenzie (2017), 'Matrix Review of Decision No. 11/2017/QDTTG of the Prime Minister Dated 11 April 2017 on the Mechanism for Encouragement of the Development of Solar Power Projects in Vietnam', retrieved from https://www. bakermckenzie.com/media/files/locations/vietnam/br_vietnam_matrixdraftdecision_ english_may17.pdf?la=en, [aceessed 16 July 2019]. 


\section{Figure 2: Ownership of Installed Capacity}

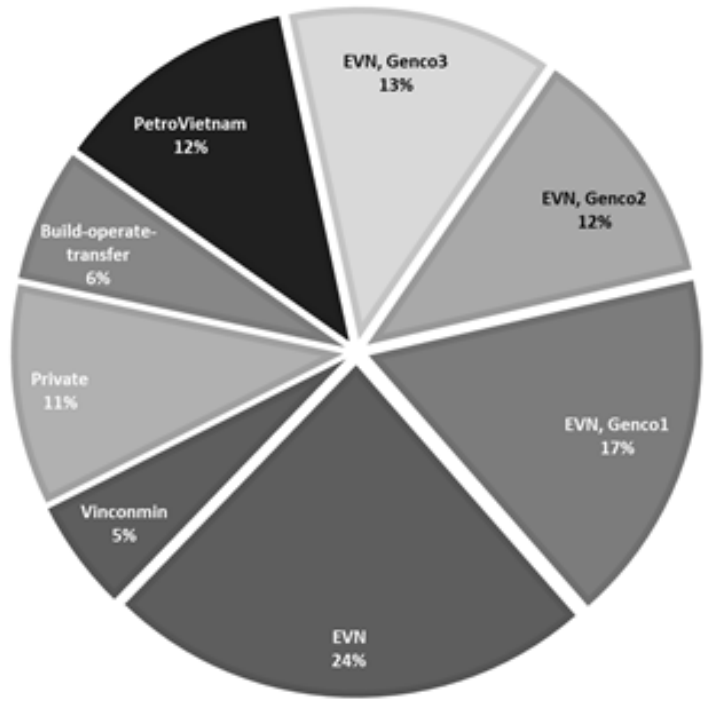

EVN = Vietnam Electricity Corp Genco = Power General

Company

(Source: EVN, 2018)

Overall, the sought-after change in market structure has not yet been effectively attained in Vietnam. The competitive electricity market has begun, but currently, very few generated power sold under PPAs are being purchased in the power market by prior-day biddings. A legal framework for a pilot wholesale competitive market is now being developed, with a long-range plan now envisioning a completely competitive electricity sector, including wholesale and retail competition, by 2024.

\section{Barriers for Deploying Renewable Energy Efficiency and Possible Solutions}

It is evident from the above sections that Vietnam's energy industry faces several challenges. This section provides an insight into the major barriers to the widespread deployment of renewable energies and energy efficiency technologies in the country and possible solutions.

(i) Policy, Regulatory and Institutional Challenges

As revealed above, only a very small portion of Vietnam's renewable energy sources is developed. This is partly due to inadequate legal, policy and institutional frameworks for renewable energies and energy efficiency sectors. The existing policy, legal and institutional frameworks are demonstrating that renewable energies and energy efficiency issues are not yet been fully taken into consideration by the country's energy industry. There are no stable policies in regard to FIT to promote renewable energies and attract investors into the industry. As analysed above, instead of a comprehensive legislation for promoting renewable energies and energy efficiency technologies, 
renewable energies and energy efficiency issues are contained in sectoral laws and policies. There is much focus on large hydropower development, while other forms of energies, such as wind, solar and biomass, are not adequately studied and deployed.

The implementation of the national energy strategy and the action plan that has been developed are not promoted by the government through a comprehensive programme. The current energy policy does not adequately take into consideration the opportunities that renewable energies and energy efficiency can provide to the country. Performance-based incentives, such as FIT, which is the most widely used policy tool for accelerating the deployment of renewable energies, would contribute in reducing investment risks and accelerate renewable energy technologies deployment if they are correctly designed and implemented. In addition to FIT, successes experienced in many countries in the region could be implemented to promote renewable energy projects. Since Vietnam's energy-related legal, policy and institutional frameworks are inadequate in accelerating renewable energies and energy efficiency deployment, a robust new policy framework should be put in place to address existing barriers. The new national renewable energy policy should contain necessary measures, such as FIT, to stimulate renewable energy investments. Rural electrification projects should be stimulated by mainstreaming renewable energies as a central technology option in the national energy policy. The policy should adequately highlight issues such as solar and biogas small scale initiatives to specifically address rural and suburban households needs. The government should also create a national agency that would be in charge of promoting renewable energies, set realistic targets for renewable energy sources, such as solar, wind and biomass, and design ways of achieving them. Measures should be put in place to ensure that industrial firms as well as small and medium-sized enterprises undergo energy audits. Means should be established to achieve the ambitious energy efficiency targets laid down in the PDMP VII.

(ii) Public awareness of the technological capacity building constraints

There is limited awareness of the benefits provided by renewable energies and energy efficiency, limited understanding of energy efficiency as a potential energy resource and inadequate training programmes and education in the field of renewable energies and energy efficiency in Vietnam. The country faces inadequate understanding on economic and environmental benefits of renewable energies and energy efficiency. The shortage of local-trained workforce to undertake renewable energies and energy efficiency projects acts as a major barrier to the large scale deployment of these technologies in the country. Technical capacity development for sustainable operation and 
maintenance of renewable energy technologies is one of the key challenges. Technical concerns, such as inadequate local technological expertise to install or maintain equipment and effectively assess available renewable resources, act as significant barriers for project developers.

There is a need to incorporate renewable energies and energy efficiency into the curriculum of secondary and higher educational institutions, promote extensive research and development in renewable energy technologies, encourage local manufacturing of renewable energy equipment, and massively sensitize the public on the importance of using renewable energy sources over conventional energy sources as well as energy efficiency. In addition, well designed training programmes must be developed to address barriers to rapid deployment of renewable energies and energy efficiency technologies. The government should make sure that capacity building and technical assistance are being directed toward policy design for policy makers.

(iii) Weak Electric Transmission Grid

One of the key challenges for the development of the energy sector and especially of renewable energies is that the national transmission grids are largely limited to urban areas, which are prone to energy losses, and there is no way to exchange available surpluses between the isolated transmission grids. There is a need for grid extension, interconnection, and modernization to minimize losses. Over the years, the system efficiency has improved, as shown by the decline in transmission and distribution losses since the concerted rehabilitation program was started in 2006. System losses fell significantly from $25.4 \%$ in 1990 to $10.1 \%$ in 2008. In 2010 and 2011, system losses increased slightly as regional low-voltage rural systems were integrated into the national grid. In 2015, the estimated system losses were of $8.4 \%$.

Currently, the national grid does not have enough capacity to accommodate to variable renewable energies. With increased variable renewable energy integration, there will be frequent grid stability problems. The grid should be improved to be strong enough to integrate renewable energy sources. There is also a need for grid stability assessment to seek how much the national grid can absorb of variable renewable energies without affecting the power quality. To better integrate renewable energies and improve grid reliability, there should be an incorporation of advanced information and communication technologies to control the power system.

Expanding electricity access cannot be achieved only through grid expansion. Off-grid energy solutions should be integrated into the rural development policy to address the challenge of inadequate energy access. 


\section{(iv) Financial constraints}

High initial capital costs for renewable technologies are a hindrance to large scale deployment in most developing countries, including Vietnam. There are inadequate funding opportunities in the renewable energies and energy efficiency sectors. There is a lack of capitals to finance renewable energies and energy efficiency deployment locally, limited trade and limited foreign direct investments to accelerate diffusion with foreign capitals. Fiscal incentives, such as long term low-interest loans, grants, and tax reductions should be put in place to address the barrier of high upfront costs. In addition, the capacity of local companies and banks should be developed in financing and operating renewable energies and energy saving projects. To enhance the diffusion of renewable energy technologies, a promising approach is to support access to technologies in rural areas where energy from small scale diesel or petrol generators is expensive as compared to grid-connected energy.

The key to accelerate renewable energy technologies deployment is the adoption of a sound legislation, technical standards and financial incentives that will provide an environment conducive for investments in renewable energies and energy efficiency. Given the intermittent nature of renewable energy sources, the cost of renewable energy technologies as compared to conventional energy and other challenges, the successful acceleration of the deployment of renewables requires a legal and regulatory framework that guarantees stable tariffs and access to the grid for Independent Power Producers, and long-term PPA to attract foreign and domestic investors. A robust energy efficiency and renewable energy policy, as well as legal framework, technology advancements and associated cost reductions in renewable energy generation, could provide enormous opportunities for Vietnam to harness its vast renewable energy resources to improve its energy security, improve economic development, reduce environmental and health impacts, and mitigate climate change by reducing greenhouse gas emissions. (v) Competitive wholesale energy market

As analysed above, one of the main issues of Vietnam is the monopolistic nature of the wholesale energy market. Despite the roadmap for the development of a competitive energy sector over the last decade, EVN still remains the only allowed buyer in the energy generation market. The National Load Dispatch Centre (NLDC), which is the System Operator, was also part of EVN. Thus, EVN plays a crucial role in the execution of the PPA with renewable energy generators.

The NLDC shall be separated from EVN and become independent; this was in recognition of the fact that the System Operator's independence 
is essential for effective competition and attracting private. However, this has not been implemented in practice.

In 2010, the then existing 11 regional power distribution companies in Viet Nam were reorganized into five power distribution corporations under EVN. These corporations are one-member limited companies 100\% owned by EVN, and were made responsible for supplying power and for the maintenance of the distribution grid up to $110 \mathrm{kV}$ over these five areas of the country: North, Central, South, Hanoi, and Ho Chi Minh City. In 2012, based on the reorganization of EVN's existing plants, the generation side of EVN was reorganized into three power generation companies, each one of them being one-member limited company 100\% owned by EVN. Each of these three power generation companies was to operate within a holding structure of EVN. The government must foster the process of equalisation/ privatisation of those EVN companies and ensure private equity participation to allow mixed ownership. The goal is to fully separate these companies from EVN once the competitive wholesale market commences.

The government may also consider developing legal basis for direct power purchase from the renewable energy generators by industrial consumers, i.e. factories and industrial parks. Under this scheme, the power generated from the renewable sources can be connected not only to the national grids system owned and operated by the EVN, but also to the consumer's facilities.

\section{Conclusion}

Vietnam is a country with great renewable energy potential. However, policy, regulatory, institutional, technical and financial inadequacy are hindering a more rapid deployment of renewable energy and energy efficiency technologies in the country. The challenges posed in terms of access to energy, energy security, volatile oil prices, climate change, poverty and health impacts are pressing, thus making the intensification of energy efficiency and renewable energy utilisation in Vietnam an imperative. With energy challenges as such, a wider use of renewable energy is increasingly important for a sustainable energy future given the vital role of sustainable, affordable and reliable energy for socio-economic development.

The key to accelerate the deployment of renewable energy technologies is the adoption of a sound legislation, technical standards and financial incentives that will provide an environment conducive for investments in renewable energy and energy efficiency. Given the intermittent nature of renewable energy sources, the cost of renewable energy technologies as compared to conventional energy and other challenges; a successful acceleration of renewables deployment requires a legal and regulatory 
framework that guarantees stable tariffs and access to the grid for Independent Power Producers, and long-term PPA which is based on market prices to attract investors. With a robust energy efficiency and renewable energy policy as well as legal framework, technology advancements and associated cost reductions in renewable energy generation, this could provide enormous opportunities for Vietnam to harness its vast renewable energy resources, improve its energy security, advance economic development, reduce environmental and health impacts, and mitigate climate change by reducing greenhouse gas emissions.

\section{Reference materials}

\section{Literature}

[1] Communist Party of Vietnam (CPV) (2018), Politburo Resolution No. 23-NQ/TW on the orientation of developing national industrial development policies till 2030, with a vision to 2045

[2] Herrmann Scheer (2006), Energy autonomy, the economic, social and technological case for renewable energy, Earthscan

[3] Hoang Quoc Vuong (2018), 'Ngành năng lự̛ng Việt Nam dang phải dối mặt với nhiều thách thứ lón' [Energy industry of Vietnam faces big challenges], VNmedia, 10/8/2018, retrieved from http://www.vnmedia.vn/kinh-te/201808/nganh-nang-luong-vietnam-dang-doi-mat-voi-nhieu-thach-thuc-lon-611423, [aceessed 12 November 2018].

[4] Preben Maegaard (2017), Balancing of Fluctuating Power to Obtain100 \% Supply with Renewable Energy, in Tanay Sidki Uyar (ed.), Towards 100\% Renewable Energy Techniques, Costs and Regional Case-Studies, Springer

[5] The World Bank (2018), The World Bank in Vietnam, retrieved from https://www. worldbank.org/en/country/vietnam/overview. [aceessed 19 December 2018]

[6] Vietnam Electricity Corporation (EVN) (2018), Báo cáo tổng kết hoạt dộng sản xuất kinh doanh ngành diẹn lục 2018 [Report on production and business activities of electric industry in 2018]

[7] MOIT, Report "Maps of solar resource and potential in Vietnam", dated 21/01/2015

[8] MOIT, Report "Potential for renewable energy development", dated 26/5/2016; see also, retrieved from http://nangluongvietnam.vn/news/en/nuclear-renewable/ expectations-on-renewable-energy-development.html, [aceessed 20 December 2018]

\section{Legal documents}

[9] Law No. 28/2004/QH11 on Electricity (2004), as amended by Law No. 24/2012/ QH13 (2012).

[10] Law No. 55/2014/QH13on Environmental Protection (2014).

[11] Decision 428/QD-TTg on master plan on the national electricity development in the period of 2011 to 2020 with vision to 2030 (2016)

[12] Decision 1208/QD-TTg by the Prime Minister approving the national master plan for power development in the 2011-2020 period, with considerations to 2030, (2011)

[13] Prime Minister's Decision No. 1855/QD-TTg approving vietnam's national energy development strategy up to 2020, with 2050 vision, (2007)

[14] Decision 2068/QD-TTg of the Prime Minister, Approving the Viet Nam's Renewable Energy Development Strategy up to 2030 with an outlook to 2050 (2015).

[15] Decision No. 11/2017/QD-TTg of the Prime Minister dated 11 April 2017 on encouragement mechanism for development of solar power projects in Vietnam (2017) (Decision 11/2017/ QD-TTg).

[16] Decision No. 63/2013/QD-TTg by the Prime Minister regarding electricity market formation roadmap (2013). 